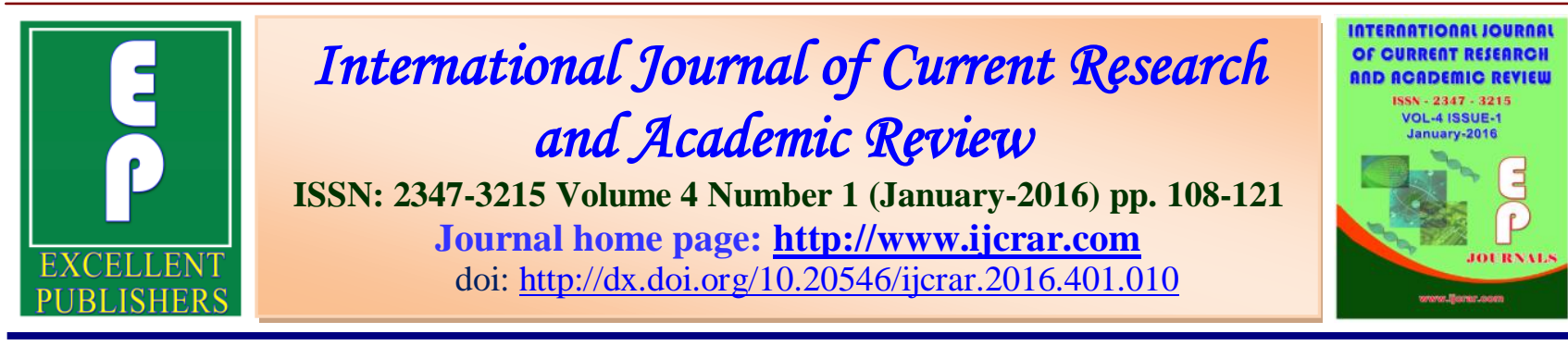

\title{
A Review on Effects of Storage on the Quality and Viability Characteristics of Major Oil Seeds
}

\section{Prashant Kumar Mishra ${ }^{1}$, Seema Paroha ${ }^{2}$ and Ravi Prakash Mishra ${ }^{1}$}

${ }^{1}$ Environmental Biotechnology Laboratory, Department of P. G. Studies and Research in Biological Science, Rani Durgavati University, Pachpedi, Jabalpur 482001, Madhya Pradesh, India

${ }^{2}$ Biochemistry Laboratory of Project Coordination Unit, All India Coordination Project (Sesame and Niger), Jawaharlal Nehru Krishi Vishwavidyalaya, Jabalpur 482004, Madhya Pradesh, India

*Corresponding author

\section{KEYWORDS}

Oilseeds, Storage, Oxidative stress, Storage containers, Deterioration

\section{A B S T R A C T}

This review was aimed to examine the changes in physiological parameter of oil seeds crop during storage. Most of these studies search for markers of germination such as increases in amylase activity or changes in free radical scavenging enzymes such as superoxide dismutase, catalase, peroxidase, and others. Protein content declines while amino acid content increases with seed ageing as seen in this study with pigeon pea seeds subjected to differing durations of accelerated ageing. Adverse environmental conditions and seed storage can cause oxidative stress in plant tissue, and development of superoxide radical, hydrogen peroxide, and hydroxyl radical, which are the most active, toxic and destructive products of oxidative stress. Antioxidants in foods and oils play an important role in maintaining the quality of foods and oils. The optimum storage conditions were found to be at $25-30^{\circ} \mathrm{C}$ and $55-65 \%$ RH. Storage containers play an important role during oil seed storage.

\section{Introduction}

Oilseed crops have been the backbone of agricultural economy of India from time immemorial. Oils extracted from plants have been used since earliest times and have been exploited in many ways. Predominantly, it is used as edible oil but it is also used in medicine and pharmaceuticals, industries, biodiesel, favorite foods and component of many other products. Dietary fat, a concentrated source of energy, supplies about half of the calories and carries fat soluble vitamins. Its by-products are being used as feed, manures and there is large 
number of oil crops grown worldwide. Total edible oil production in $2012-13$ is likely to increase to 7.3 million tons, 3 percent more than the previous year. Most of the increase is likely to be in rapeseed-mustard oil. Edible oil production for the recent marketing year is estimated at 7.1 million tons, which includes 2.3 million tons of rapeseed oil, 1.7 million tons of soybean oil, 1.3 million tons of peanut oil, and 1.2 million tons of cottonseed oil, and 600,000 tons of coconut, palm and sunflower oils (Anon, 2012).

Sesame seed oil is premium oil, exported in significant quantity to provide to the growing demand from overseas buyers. During the year 2010-11, India earned a foreign exchange to the tune of 7.2 million dollars from sesame seed exports. The major destinations of Indian sesame oil are Mexico, China, UAE, United States of America, Singapore, and Malaysia. Oilseed production in India is mostly rain-fed, and is an important source of livelihood for small and marginal farmers in the arid and semiarid areas of the country. During the twelfth five-year plan period, the Government of India has provided, through its "National Mission on Oilseeds and Oil Palm (NMOOP)," various support and incentive programs for oilseed growers. NMOOP replaces the old Integrated Oilseeds, Oil Palm, Pulses and Maize Development program, which was under performance in 14 major states for oilseeds and pulses, 15 for maize and 9 for oil palm. As agriculture is a state subject, the central-government program is likely to supplement efforts by state governments to enhance oilseed production and productivity (Anon, 2012).

Region where oil seed crops are growing increasing every year but the required quantity of high quality seeds are not available for sowing in time to the farmers.
Non-availability of seeds is mainly due to lower seed yield, constraints in seed production, lesser area in seed production and lesser participation of farmers owing to involvement of high risk, finance and technical knowledge. Further nonavailability of seed is also due to rapid loss of viability of oil seeds compared to cereals and pulses as oil seeds contain more of poly unsaturated fatty acids which undergo rapid deterioration owing to lipid autoxidation and fungal activity. The results of these processes are not only the lipid degradation, but a series of reactions some of which form toxic products. Fatty acid composition is the most important factor which determines oils susceptibility to oxidation (Morello et al., 2004

The temperature, moisture and storage duration are the most important individual factors which affect on stored product quality and quantity. Under unfavorable conditions such as the temperature above $30^{\circ} \mathrm{C}$ and relative air humidity from 80 to 90 per cent, the variation in seed germination rate can be high (Sisman, 2005).

Seed aging during storage is an inevitable phenomenon, but the degree and speed of decline in seed quality depend strongly, beside storage conditions, on plant species stored and initial seed quality (Elias and Copeland, 1994; Balesevic et al., 2005).

The purpose of storage is to maintain harvest quality of product but not to improve it (Sisman and Delibas, 2004). The rate at which the seed aging process takes place depends on the ability of seed to resist degradation changes by protection mechanisms which are specific for each plant species (Balesevic et al., 2001). Seeds of different plant species lose viability to a various degree even when kept under the same storage conditions. Accelerated aging 
of seed, i.e., seed lot exposure to high temperature and high relative humidity leads to a loss of vigor and finally to a loss of viability which is an outstanding method for determination of changes in vigor during seed storage (Tian et al., 2008).

Sometimes, the invigorated seeds will remain unsown for want of proper soil conditions. Under such situations, the seeds need to be stored till next sowing season. The information on storability of such seeds needs to be generated.

\section{Seed Deterioration}

Seed deterioration during storage is a complex physiological and biochemical process leading to loss of germination ability. Seed quality could be evaluated by testing seed germination and seed germination index in both laboratory scale and green house. On the other hand, the biochemical changes during seed deterioration such as chromosomal aberrations damage to the DNA, changes in the synthesis of RNA and protein, changes in enzymes, differences in respiratory activity caused by ATP production and membrane alteration are not completely understood (Kerter et al., 1997) Many researchers have reviewed the membrane alteration because the cell membrane was the first part of the cells to interact with the environment and suggested the lipid oxidation of the cell membrane might underlie loss of seed viability (Kaloyereas, 1958; Spano et al., 2006). Many researchers analyzed phospholipids changes and raised the possibity that membrane peroxidation was associated with aging (RandhirandShetty, 2005; Kerter et al., 1997).

Seed of oil crops are highly vulnerable to deterioration. They cannot be stored for a long time and are described to have poor storage capacity. The seed quality of peanut and soybean is difficult to maintain in storage. Sesame seed was found to be a 'poor sorer' compared with soybean and peanut seed. In oil seed crops, the seed quality is significantly affected by unfavorable storage conditions. Changes that occur in seed during aging are significant in terms of seed quality, the feature that, among other things, also implies seed longevity (Milosevic and Malesevic, 2004).

Seeds deteriorate during storage, aging is manifest as a reduction in percentage germination, resulting less and weak seedlings. During the aging process, seeds lose their vigor, ability to germinate and ultimately become less viable (Maity et al., 2000). Losses in seed quality occur during field weathering, harvesting and storage. The losses are exacerbated if seeds are stored at high temperatures or conditions of high relative humidity. Cottonseed is one of the most sensitive agronomic seeds susceptible to significant deterioration after just one year's storage. Cottonseed like other oil seeds is more prone to deterioration due to its high oil content (Powell et al., 2000).

\section{Enzymatic Activity}

Most of these studies search for markers of germination such as increases in amylase activity or changes in free radical scavenging enzymes such as superoxide dismutase, catalase, peroxidase, and others. Protein content declines while amino acid content increases with seed ageing as seen in this study with pigeon pea seeds subjected to differing durations of accelerated ageing. This suggests that proteins are being degraded into their constituent parts during ageing. A trend of decreased DNA synthesis 
and increased DNA degradation has been reported. It is widely believed that degradation of DNA would lead to faulty translation and transcription of enzymes necessary for germination. A second possibility is that DNA remains functional resulting in the formation of functional stored mRNA. During storage, the stored mRNA may be degraded leading to impaired transcription causing incomplete or faulty enzyme synthesis essential for the earliest stages of germination. Without enzyme activity, storage reserves are not hydrolyzed and energy molecules remain unavailable for the synthesis of ATP. This results in slower seedling growth. It has been well documented that certain anabolic enzymes help in maintaining viability while some catabolic enzymes decrease viability. Free radicals and hydrogen peroxides are produced from various metabolic reactions and could be destroyed by the activity of scavenger enzymes like catalyse and hydrogen peroxidase. Peroxidase activity decrease appreciably with ageing making the seeds more sensitive to the effects of oxygen and free radicals in membrane unsaturated fatty acids and to the production of secondary lipid peroxidation products such as monaldehyde and lipid conjugants. Association of loss of viability with enzymatic activity decline was reported in barley (Harrison and Perry, 1976) and in sorghum (Perl et al., 1978).

\section{Seed Viability}

Loss of seed viability in storage has also been related to enzymatic activity by AbdulBaki (1980) who pointed out that the respiratory and associated enzymes viz., paroxidase, glutamic acid oxidase and catalase activity decreased with loss of seed viability. While, the activity of hydrolytic enzymes viz., phytase, protease and phosphatase increased during storage. The increased activity of these enzymes was associated with the degradation of organocellular membranes, nucleoproteins, etc. Similar decline in peroxidase activity with increase in storage period has been reported by Nkang (1988).

Francis and Coolbear (1988) reported accumulation of phospholipase activity in aged seeds of tomato which acts on membrane phospholipids and releases fatty acids, thus indicating the loss of membrane phospholipid and subsequent lipid peroxidation.

Biochemical changes in free amino acids, free sugars and volatile aldehydes such as pentane, ac et aldehyde and methanol is a consequence of lipid peroxidation mediated by free radicals and lipoxygenase enzymes (Wilson and McDonald, 1986).

Lipase production in storage conditions by pathogens like Aspergillus flavus and Pencillium sps. leads to seeds spoilage in linseed (Saraswat and Mathur, 1985).

Zhang et al. (1993) suggested that the decrease in lipoxygenase activity was related to the increase in protein content.

Taung and McDonald (1995) reported that enzymes and free lipid hydroperoxides also damage membranes and leads to lipid autoxidation reaction in groundnut.

Increase in propetinase, polygalactrunase, pectidepolymerase and lipase enzymes activity resulted in seed deterioration by reducing total germination and oil content and increase in free fatty acid in safflower (Saxena and Mohana, 1998).

During germination and seedling development, seed storage proteins are typically degraded by proteases that convert 
the insoluble storage proteins into soluble peptides and then by hydrolases to generate free amino acids. These free amino acids are available for transport to the embryonic axis to support growth and as an energy source (Shutov and Vaintraub 1987; Bewley and Black 1994; Muntz et al., 2001).

There are no reports available on the changes in protein profiling pattern during seed maturation, germination and subsequent seedling growth that contribute to major component of seed development in P. pinnata. The same is true of the other reproductive and vegetative tissues in $P$. pinnata. Much is already known about protein storage and fine structural changes during seed maturation and germination of other oil seed crops (Bhandari and Chitralekha 1984; Prego et al., 1998; Borisjuk et al., 2005; Neuberger et al., 2008).

Lipase is the principle enzyme involved in oil body mobilization during seed germination, which catalyzes the cleavage of carboxyl ester bonds of TAGs, releasing free fatty acids (FFAs) and glycerol (Feussner et al., 2001).

During storage time product specially stored oils compositions can be influenced by several storage conditions. A fatty acid composition is the most important factor which determines oils susceptibility to oxidation. The types of fatty acids present in an oil, and in particular their number of double bounds, determine the type and extent of chemical reactions which occur during the storage time (Morello et al., 2004).

\section{Oxidative Stress}

Free radicals which have one or more unpaired electrons are produced in normal or pathological cell metabolism. Reactive oxygen species (ROS) react easily with free radicals to become radicals themselves. ROS are various forms of activated oxygen, which include free radicals such as superoxide anion radicals and hydroxyl radicals, as well as non-free radical like hydrogen peroxide species and the singlet oxygen (Halliwel 1997; Squadriato et al 1998; Yildrim., et al 2001).

The hydroxyl radical is a very strong oxidant and can initiate radical chain reaction with organic molecules, particularly with poly unsaturated fatty acids in membrane lipid.

Initiation of the reaction sequence involves the reaction of hydroxyl radical with the mthylene group $\left(\mathrm{CH}_{2}-\right)$ adjacent to a double bond of unsaturated fatty acids (RH) to give lipid free radical (Roo) and peroxy radical $(\mathrm{H})$ the lipid free redical reacts with molecular oxygen to give a lipid peroxy radical (ROO-) which may attack another lipid and in so doing produce a lipid hydro peroxide $(\mathrm{ROOH})$ as well as initiate a new lipid radical $(\mathrm{R})$ and hence produce autocatalytic reaction the lipid hydro peroxide if further decomposed to wide varieties peroxidation produce the main one of which is malondealdehyde (MDA) (Forman and fisher, 1981).

Almost all organisms are well protected against free radical damage by antioxidant when the mechanism of antioxidant protection becomes unbalanced by the deterioration of cell, oxidation can occur which result in accumulation of free radical The antioxidant is important to find compound that prevent oxidation (Khanahmadi et al., 2010).

Adverse environmental conditions and seed storage can cause oxidative stress in plant 
tissue, and development of superoxide radical, hydrogen peroxide, and hydroxyl radical, which are the most active, toxic and destructive products of oxidative stress. The composition of fatty acids is the most important factor which determines oils susceptibility to oxidation. The types of fatty acids present in oil, and in particular number of their double bonds, determine the type and extent of chemical reactions which occur during the storage time (Morrelo et al., 2004)

Lipid peroxidation (LP) is oxidative damage of cell membranes, lipoproteins and supplementary molecules containing lipids, caused by oxidative stress. Once initiated, reaction of LP continues auto-catalytically and increasingly leads structural and functional substrate changes (Popovic et al., 2001).

According to the degree of reactivity, the most reactive amino acids sensitive to oxidative damages are cysteine, histidine, tryptophan, methionine and fenilalanin.

\section{Antioxidative Activity}

Antioxidants are a group of compounds that facilitate survival in plants and may promote the health of humans that consume a variety of plant foods (Connor et al., 2002; Lampart-Szczapa et al., 2003; Mojzisova and Kuchta, 2001; Shahidi, 2000). In plants, the term antioxidant often refers to a wide range of phenolic compounds that vary from simple phenolic acids to highly polymerized compounds such as tannins. Phenolic compounds, or polyphenols, are categorized into 15 main classes with over 8,000 identified compounds. The largest category is the flavonoid group, comprising 13 classes with over 5,000 compounds (Fine and Candidate, 2000; Harborne, 1998; KrisEtherton et al., 2002).
These adverse conditions increase the formation of reactive oxygen species (ROS)such as $\mathrm{H}_{2} \mathrm{O}_{2}$ (hydrogen peroxide), $\mathrm{O}_{2}-\quad$ (superoxide)and $\mathrm{OH}$ (hydroxyl) radicals, through enhanced leakage of electrons to molecular oxygen (Arora et al., 2002). ROS can act as second messengers involved in the stress signal transduction pathway (Chamnongpol et al., 1998), but excessive ROS production can cause oxidative stress, which damages plants by oxidizing photosynthetic pigments, membrane lipids, proteins and nucleicacids (Yordanov et al., 2000). To keep the levelsof active oxygen species under control, plants have non-enzymatic and enzymatic antioxidant systems to protect cells from oxidative damage (Mittler, 2002). Nonenzymatic antioxidants including $\beta$ carotenes, ascorbic acid (AA), $\alpha$-tocopherol $(\alpha$-toc), reduced glutathione (GSH) and enzymes including: superoxide dismutase (SOD), guaiacol peroxidase (POD), ascorbate peroxidase (APX), catalase (CAT), polyphenol oxidase (PPO) and glutathione reductase (GR) (Xu et al., 2008). Superoxide dismutases (SODs), a group of $\mathrm{m}$ et alloenzymes, are considered as the first defence against ROS, being responsible for the dismutation of $\mathrm{O}_{2}-$ to $\mathrm{H}_{2} \mathrm{O}_{2}$ and $\mathrm{O}_{2}$. CAT, APX, POD are enzymes that catalyze the conversion of $\mathrm{H}_{2} \mathrm{O}_{2}$ to water and $\mathrm{O}_{2}$ (Gratao et al., 2005). The balance between ROS production and activities of antioxidative enzymes determines whether oxidative signalling and damage will occur (Moller et al. 2007). The capability of scavenging ROS and reducing their damaging effects may correlate with the drought tolerance of plants (Tsugane et al., 1999). Furthermore, the reactions of the plants to water stress differ significantly at various organizational levels depending upon intensity and duration of stress as well as plant species and its stage of development (Chaves et al. 2003; Jung 2004; Dacosta \& 
Huang 2007). There are many reports in the literature that underline the intimate relationship between enhanced or constitutive antioxidant enzyme activities and increased resistance to environmental stresses in several plant species, such as rice (Guo et al., 2006), foxtail millet (Sreenivasulu et al., 2000), tomato (Mittova et al., 2000), sugar beet (Bor et al., 2003), wheat (Khanna-Chopra \& Selote 2007) and barley (Acar et al., 2001).

Antioxidants in foods and oils play an important role in maintaining the quality of foods and oils. During chemical refining of edible oils the natural antioxidants and antioxidant precursors might be removed (El-Mallah et al., 2011).

Sesame contains substantial amounts of unique components called lignans (sesaminand and sesamolin), which play an important role in promoting health. Sesamin and sesamolin have been reported to have many bioactive properties, e.g. antioxidant activity, antiproliferative activity, lowering cholesterol levels, and showing antihypertensive effects and neuro protective effects against hypoxia or brain damage (Rangkadilok et al., 2010).

\section{Varieties on Seed Quality}

High quality seed that provides adequate plant stand is the basis for profitable production and expansion of soybean crop. In order to increase the production of soybean, a source of high quality, disease free seed must be established and maintained. Loss of viability and vigour under high temperature and $\mathrm{RH}$ conditions is a common phenomenon in many crop seeds but it is well marked in soybean.

Shelar (2002) carried out research on soybean seed quality during storage and reported that the germination of soybean varieties decreased during storage irrespective of varieties, threshing and processing methods and storage containers.

The optimum storage conditions were found to be at $25-30^{\circ} \mathrm{C}$ and $55-65 \% \mathrm{RH}$. The viability of soybean variety JS-335 and MACS-124 could be maintained up to certification standard for 330 and 270 days, respectively under ambient conditions of Rahuri (Shelar, 2002).

Those colored to soybean seeds showed differences in seed quality and insect damage. Seeds coated with $H$. rosasinensis and polykotecolours showed higher per cent germination compared to control (Keshavulu and Krishnasamy 2005).

Krishnappa et al. (2001) observed significant vari et al differences in germination, vigour index, seedling dry weight and electrical conductivity; cultivar ICGS-30 and DH-3- 301 retained satisfactory germination above the minimum seed certification standards even after 12 months of storage, while TAG-24 and ICGS-10 for only eight months under ambient storage conditions of Bangalore.

Diwakar et al. (2002) observed the vari et al difference in the storability of sesamum. They found that TKG-21 was having the most table and nutritionally best quality oil as compared to RS-160, OS-10, OS-18, ORM-17, JTS-8 and TC-25, RT-274.

Deshpande et al. (2003) noticed groundnut vari et al differences in storage potential. Among the varieties R-8808 maintained satisfactory germination for 7 months, ICGS-11 for 6 months and JL-24 for 5 months when stored in cloth bag under ambient storage condition of Dharwad. Verma et al. (2003) reported that mustard 
variety RH-8113 maintained satisfactory germination upto 3 years with increase root length, shoot length, seedling dry weight, and seedling vigour, and oil content, field emergence compared to variety $\mathrm{RH}-30$.

Anuja Gupta and Aneja (2004) reported that soybean cv. Pusa-16 maintained higher germination $(85.8 \%)$ with lower leakage of electrolytes and amino acid of about 42 per cent and 39.5 per cent respectively compared to variety JS-80-21.

\section{Effect of Containers on Storage}

Patra et al. (2000) revealed that groundnut seeds stored in gunny bag lost viability with advancement of storage period and became nil after 9 months of storage compared to seeds stored in polythene bag.

In the pods of groundnut cultivar TMV-2 stored in different packaging materials under ambient condition at Bangalore, Narayanaswamy et al. (2001) observed that the pods stored in the poly lined gunny bag (400 guage) had retained germination above the minimum seed certification standards $(>70 \%)$ for 12 months, while high density polythene bag and gunny bag for 10 and 8 months, respectively. Similar trend was observed for field emergence.

Padma and Muralimohan Reddy (2001) stated that storability of soybean cultivars could be improved by four months after storing seed in polythene bag compared to cloth bag.

Kurdikeri et al. (2003) observed significant vari et al difference for germination in groundnut. Among six genotypes of groundnut stored in cloth bag under ambient condition of Dharwad, cvs. DH-330, JL-24, TMV-2 and ICGS-76 maintained satisfactory germination as per MSCS (70\%) upto 15 months, while, Mardur local and DH-40 for 11 and 9 months, respectively.

Manomani (2002) reported that groundnut seeds stored in cloth bag maintained satisfactory germination only for 6 months of storage.

Moholkar et al. (2002) concluded that sunflower cv. 6D-1 maintained above MSCS upto 20 months by drying the seeds to 8 per cent moisture content in polythene bags (700 guage) where in cloth bags upto 10 months of storage.

The germination percentage was affected by packaging materials during storage. High germination percentage can be maintained for 14 months in seeds packed in 700 guage polythene bags whereas, it fell to 3 per cent and 1 per cent, respectively in seeds packed in cloth bags by 8 months (Singh and Dadlani 2003).

Those seeds packed in polythene bags retained seed viability for 15 months and 9 months in untreated seeds in cloth bags (Gupta and Aneja 2004).

Krishnappa et al. (2003) reported that groundnut pods stored in high density polythene bag retained germination above the minimum seed certification standards $(>70 \%)$ for 15 months with higher vigour index, while in cloth bag retained for 14 months with lower vigour index.

Singh and Dadlani (2003) reported that soybean seeds stored in cloth bag maintained satisfactory germination only for 4 months of storage.

Chowdhury et al. (2003) reported that seeds of groundnut Amber maintained satisfactory germination up to 2 months stored in gunny bag and for 8 months in polythene bag. 


\section{Conclusion}

In any crop success of seed production ends with safe storage of seeds. Now-a-days much importance is being given to storage of seeds as "Seeds saved is seed produced". Not all kinds of seeds store equally well, as storability is mainly under genetic control but modified by the environment in which the seeds are stored. Apart from genetic factor, storage potential also varies among genera, species, and varieties and even it extends to seed lots. Further among different crop seeds, oilseeds are considered to be very poor stores followed by starch rich cereals which are classified as medium stores while, protein rich seeds of pulses as good stores.

Loss of seed viability due to ageing and deteriorative changes in storage is characterized as inexorable, irreversible, and inevitable but the rate of deterioration can be slowed down by storing the seeds under controlled conditions at lower relative humidity and temperature. But storage under controlled conditions seems to be very costly in developing countries like India. Hence, storage of seeds in natural places (locations) where, ambient temperature and relative humidity are relatively low seems to be better to maintain seed quality which will be less costly compared to controlled conditions seed storage.

Several storage fungi are known to invade seeds during storage and their occurrence is dependent on seed moisture content, prevailing relative humidity and temperature. Generally storage fungi are saprophytic and will be very active at higher seed moisture content $(12 \%)$, relative humidity $(>70 \%)$ and temperature $\left(25-30^{\circ} \mathrm{C}\right)$ and cause much damage to seeds both in quality and quantity. In the present study it was evident that invasion of fungi was less in the seeds stored. Pathological investigations in sunflower, and also in soybean showed higher frequency of storage fungi in stored seeds and was ascribed to favorable atmosphere prevailed for the growth of storage fungi.

Oil content with increase in storage period in mustard, groundnut, and also in soybean. The decrease in oil content has been related to peroxidation of lipid by peroxidase enzyme in mustard and soybean.

Seeds revision would definitely help the farmers to sow the quality seeds which safe guard the farmers from the deserters of sowing low quality seeds.

\section{Acknowledgement}

Authors are thankful to Head, Dept. of P.G. Studies and Research in Biological Science, R.D. University, and Project Coordination Unit, All India Coordination Project (Sesame and Niger), Jawaharlal Nehru Krishi Vishwavidyalaya, Jabalpur (M.P).

\section{References}

Abdul-Baki, A.A. 1980. Biochemical aspects of seed vigour. Horticultural Science, 15: 765-770.

Acar, O., Turkan, I., and Zdemir, F.O. 2001. Superoxide dismutase and peroxidase activities in drought sensitive and resistant barley Hordeumvulgare L. varieties. ActaPhysiologiaePlantarum, 3: 351-356.

Anonymous. 2012. Indian Agriculture, report no. IN2048, pp.1:6.

Anujagupta and Aneja, K.R. 2004. Seed deterioration in soybean varieties during storage: Physiological Attributes. Seed Research, 32: 26-32. 
Arora, A., Sairam, R.K., and Sriuastava, G.C. 2002. Oxidative stress and antioxidative system in plants. Current Science, 82: 1227-1238.

Balesevic-Tubic, S. 2001. Uticaj procesas tarenjanazivotnusposobnost biohemijske promene semena suncokreta. Doktors kadisertacija, Poljoprivrednifakultet, Novi Sad.

Balešević-Tubić, S., Malenčić, D., Tatić, M. and Miladinović, J., 2005. Influence of aging process on biochemical changes in sunflower seed. Helia 28: 107-114.

Bewley, J.D., and Black, M. 1994. Cellular events during germination and seedling growth. In: Bewley JD, Black M, eds. Seed Physiology of Development and Germination. New York: Plenum Press, 147-197.

Bhandari, N.N., and Chitralekha, P. 1984. Degradation of protein bodies in germinating seeds of Brassica campestris L. var. sarsonPrain. Annals of Botany 53: 793-801.

Bor, M., Ozdemir, F., and Turkan, I. 2003. The effect of salt stress on lipid peroxidation and antioxidants in leaves of sugar beet Beta vulgaris $\mathrm{L}$ and wild beet BetamaritimaL. Plant Science, 164: 77-84.

Borisjuk, L., Nguyen, T.H., Neuberger, T., Rutten, T., Tschiersch, H., Claus, B., Feussner, I., Webb, A.G., Jakob, P., Weber, H., Wobus, U., and Rolletschek, H. 2005. Gradients of lipid storage, photosynthesis and plastid differentiation in developing soybean seeds. New Phytologist 167: 761-776.

Chamnongpol, S., Willekens, H., Moeder, W., Langebartels, C., Sandermann, H., Van, M.M., Inze, D., and Van, C.W. 1998. Defense activation and enhanced pathogen tolerance induced by $\mathrm{H}_{2} \mathrm{O}_{2}$ in transgenic
tobacco.Proceedings of the National Academy of Science of the United States of America, 95: 5818-5823.

Chaves, M.M., Maroco, J.P., and Pereira, J.S. 2003. Understanding plant responses to drought-from genes to the whole plant. Functional Plant Biology, 30: 239-264.

Chodhwary.,Mathur, D.S., Lal and Jayprakash. 2003. Seed research on groundnut under NSP crops. Proceedings of National Workshop on Groundnut SeedTechnology, Feb 6-7, pp. 6-19.

Connor, A.M., Luby, J.J., Tong, C.B.S., Fin, C.E., and Hancock, J.F. 2002. Genotypic and environmental variation in antioxidant activity, total phenolic content and anthocyanin content among blueberry cultivars.Journal of the American Society for Horticultural Science. 127: 89-97.

Dacosta, M., and Huang, B. 2007. Changes in antioxidant enzyme activities and lipid peroxidation for bentgrass species in responses to drought stress. Journal of the American Society for Horticultural Science, 132: 319-326.

Deshpandey, V.K., Sarwad, R.K., and Shekaraguda, M. 2003. Accelerated ageing test - A tool to predict relative storability in groundnut. Proceedings of NationalWorkshop on Groundnut Seed Technology, Feb. 6-7, pp. 171176.

Diwakar, S.K., Madhu, Vajpeyi, and Singh, P.K. 2002. Quality studies of some sesame Sesamum indicum L. seeds, oil, protein and fatty acids. Journal of OilseedResearch, 19: 71-72.

Elias, S.G., and Copeland, L.O., 1994. The effect of storage conditions on canola Brassica napusL. seed quality. Journal of Seed Technology 18: 2122. 
EL-Mallah, M.H., S.M. EL-Shami, M.M.M. Hassanien, and A.G. Abdel-Razek. 2011. Effect of chemical refining on the minor and major components of cottonseed oil. Agriculture and Biology Journal of North America, 2: 341-349.

Feussner, I., Kuhn, H., and Wasterneck., C. 2001. Lipoxygenase-dependant degradation of storage lipids. Trends Plant Science, 6:268-73.

Fine, A.M., C.P.A., and Candidate, N.D. 2000. Oligomericpro anthocyanidin complexes: history, structure, and phytopharmaceutical applications. Alternative Medicine Review5: 144151.

Forman, H.J., and Fisher, A.B. 1981. Antioxidant Defenses. In: Oxygen and Living Processes. An Interdiscriplinary Approach, Gilbert, D.L., Ed..Springer-Verlag, Berlin. pp 235-249.

Francis, A. and Coolbear, P., 1988. Changes in the fatty acid content of the polar lipid fraction of tomato seeds induced by ageing and/or subsequent low temperature presowing treatment. Seed Science and Technology, 16: 8795.

Gratao, P.L., Polle, A., Lea, P.J., and Azevedo, R.A. 2005. Making the life of heavy m et al-stressed plants a little easier. Functional Plant Biology, 32: 481-494.

Guo, Z., O.u. W., Lu, S., and Zhong, Q. 2006. Differential responses of antioxidative system to chilling and drought and in four rice cultivars differing in sensitivity. Plant Physiology and Biochemistry, 44: 828-836.

Gupta, A. and Aneja, K. R. 2004. Seed Res. 32: $26-32$.
Halliwell, B. 1997. Antioxidants and human diseases: a general introduction. Nutritional Review. 55, S44 S52.

Harborne, J.B. 1998. Phytochemical Methods: A Guide to Modern Techniques of Plant Analysis, 3rd ed., St. Edmundsbury Press, Bury St. Edmunds, Suffolk p 40.

Harrison, J.G. and Perry, D.A. 1976. Studies on the mechanism of barley seed deterioration. Annals of Applied Biology, 84: 57-62.

Kaloyereas, S.A. 1958. Rancidity as a factor in the loss of viability of pine and other seeds. Journal of the American Oil Chemists' Society. 35:176-179.

Kerter, S.T., Geneve, R.L., and Houtz, R.L. 1997. Priming and accelerated aging affect L-isoaspartylmethyltransferase activity in tomato Lycopersicones culentum Mill. seed. Journal of experimental botany, 48:943-949.

Keshavulu, K. and Krishnasamy, V. 2005. Effect of seed colouring on seed quality and bruchid damage in soybean. Seed Research, 33: 208-210.

Khanahmadi, M., S.H. 2010. Rezazadeh and antioxidant properties of Smyrnium cordifolium Boiss. Umbelliferae extract. Asian Journal of Plant Science. 9: 99-103.

Khanna-Chopra R., and Selote D.S. 2007. Acclimation to drought stress generates oxidative stress tolerance in drought-resistant than -susceptible wheat cultivar under field conditions. Environmental and Experimental Botany, 60: 276-283.

Kris-Etherton, P.M., PhD, RD, MS, RD, Hecker, K.D., M.S, R.D, Bonanome, A., MD, Coval, S.M, MS, Binkoski, A.E., BS, RD, Hilpert, KF, BS, Griel, A.E., Med, Etherton TD, PhD 2002. Bioactive compounds in foods: their role in the prevention of cardiovascular disease and cancer. 
Int.J.Curr.Res.Aca.Rev.2016; 4(1): 108-121

American Journal of Medical

Genetics, 113: 71-88.

Krishnappa, N., Narayanaswamy, S., Balakrishna, P. and Lokesh, K. 2003. Influence of storage mycoflora on seed quality of groundnut ArachishypogaeaL. varieties stored in different packing materials. Proceedings of National Workshop onGroundnut seed Technology, Feb. 6-7, pp. 6-19.

Krishnappa, N., Narayanaswamy, S., Sreenavasa, R. and Kumar, C. 2001. Seed quality as influenced by natural storage and accelerated ageing in groundnut cultivars. Mysore Journal of Agricultural Sciences, 35: 37-43

Kurdikeri, M.B., Giriraj, K. and Shekhar Gouda, M. 2003. Storage potential of groundnut seeds under ambient conditions. In : Proceedings of National Workshop onGroundnut Seed Technology, Ed. Basavegowda, et al. University of Agricultural Sciences, Campus, Raichur during February 6-7, 2003, pp. 168-170.

Lampart-Szczapa, E., Korczak, J., NogalaKalucka, M., and Zawirska-Wojtasiak, R. 2003. Antoxidant properties of lupin seed products. Food Chemistry, 83:279-285.

Maity, S., Banerjee, G., Roy, M., Pal, C., Pal, B., Chakrabarti, D., and Bhattacharjee, A. 2000. Chemical induced prolongation of seed viability and stress tolerance capacity of mung bean seedlings. Seed Science and Technology, 28: 155-162.

Manomani, V. 2002. Storability of dormant and non-dormant cultivars of groundnut ArachishypogaeaL.. Seed Research, 30: 158-160.

Milošević, M., and Malešević, M. 2004. Semenarstvo. Naučni institutzaratarstvo i povrtarstvo, Novi Sad: 110-114.
Mittler, R. 2002. Oxidative stress, antioxidants and stress tolerance. Trends in Plant Science, 7: 405-410.

Mittova, V., Volokita, M., Guy, M., and Tal, M. 2000. Activities of SOD and the ascorbate-glutathione cycle enzymes in subcellular compartments in leaves and roots of the cultivated tomato and its wild salt-tolerant relative Lycopersiconpennellii.

PhysiologiaPlantarum, 110: 42-51.

Moholkar, N.D., Mate, S.N. Shelar, V.R., Mansare, M.R. and Bharud, R.W. 2002. Physico-chemical treatment for extension of storability of seeds of male parent 6D-1 of sunflower Hybrid KBSH-1. Seed Research, 32: 159-160.

Mojzisova, G., and andKuchta, M. 2001. Minireview: Dietary flavonoids and risk of coronary heart disease. Physiologicalrsearch. 50:529-536.

Moller, I.M., Jensen, P.E., and Hansson, A. 2007. Oxidative modifications to cellular components in plants. Annual Review of Plant Biology, 58: 459-481.

Morello, J.R., Motilva, M.J., Tovar, M.J., and Romero, M.P. 2004. Changes in commercial virgin olive oil CV Arbequina during storage with special emphasis on the phenolic fraction. Journal of Food Chemistry, 85: 357364.

Muntz, K., Belozersky, M.A., Dunaevsky, Y.E., Schlereth, A., and Tiedemann, J. 2001. Stored proteinases and the initiation of storage protein mobilization in seeds during germination and seedling growth. Journal of Experimental Botany, 52: 1741-1752.

Narayanaswamy, S. 2003. Effect of packaging and location of storage on groundnut seed. In : Proceedings of National Workshop on Groundnut Seed Technology, Ed. Basavegowda, et al. University of Agricultural 
Sciences Campus, Raichur during February 6-7, 2003, pp. 164-167.

Narayanaswamy, S., Rajendra Prasad, S. and Vijaymoha Reddy. 2001. Effect of packaging materials on seed quality in groundnut for bulk seed storage. Proceedings of National Seminar on Seed Science and Technology in New Millennium - Vistas and vision. August 6-8, 2001, Mysore, India, p. 196.

Neuberger, T., Sreenivasulu, N., Rokitta, M., Rolletschek, H., Gobel, C., Rutten, T., Radchuk, V., Feussner, I., Wobus, U., Jakob, P., Webb, A., andBorisjuk, L. 2008. Quantitative imaging of oil storage in developing crop seeds. Plant Biotechnology Journal 6: 31-45.

Nkang, A. 1988. Some aspects of biochemical basis of viability of loss in stored qukfaylla seeds. Seeds Science and Technology, 16: 247-260.

Padma, V. and Muralimohan and Reddy, B. 2001. Seed invigoration for extending storability of soybean seed. Journal of Research Acharya N.G. Ranga AgriculturalUniversity, 29: 1-5.

Patra, A.K., Tripathy, S.K. and Samui, R.C. 2000. Effect of drying and storage methods on seed quality of summer groundnut ArachishypogaeaL.. SeedResearch, 28: 32-35.

Perl, M., Luria, I. and Gelmond, H. 1978. Biochemical changes in sorghum seeds affected by accelerated ageing. Journal of Experimental Botany, 29: 479-509.

Popovic, B. 2001. Influence of $\gamma$ - radiation on antioxidative system of selected soybean genotypes and appearance of oxidative stress. Thesis Ph.D. University of Novi Sad, Novi Sad.

Powell. A.A., Yule, L.J., Jing, H.C, Groot, S.P.C., Bino, R.J., and Pritchard, H.W. 2000. The influence of aerated hydration seed treatment on seed longevity as assessed by the viability equations. Journal of Experimental Botany, 51: 2031-2043.

Prego, I., Maldonado, S., and Otegui, M. 1998. Seed structure and localization of reserves in Chenopodiumquinoa. Annals of Botany, 82: 481-488.

Rangkadilok, N., N. Pholphana, C., Mahidol, W., Wongyai, K., Saengsooksree, S., Nookabkaew, J., and Satayavivad. 2010. Variation of sesamin, sesamolin and tocopherols in sesame Sesamim indicum $L$. seeds and oil products in Thailand. Food Chemistry, 122: 724-730.

Saraswat, R.P. and Mathur, S.K. 1985. Lipase production by seed borne fungi of linseed. Seed Research, 13: 123124.

Saxena, N., Karan, D. and Mohana. 1998. Enzymatic studies of seed borne fungi of safflower seeds and their role in seed deterioration during storage. Seed Technology News, 28: 25-26.

Shahidi, F. 2000. Mini-review: Antioxidant factors in plant foods and selected oilseeds. BioFactors 13: 179-185.

Shelar, V.R. 2002. Ph D. Thesis MPKV, Rahuri MS.

Shutov, A.D., and Vaintraub, I.A. 1987. Degradation of storage proteins in germinating seeds. Phytochemistry 26: 1557-1566.

Singh, K. K. and Dadlani, M. 2003. Seed Research, 31: 27 - 32.

Sisman, C. 2005. Quality losses in temporary sunflower stores and influences of storage conditions on quality losses during storage. Journal of Central European Agriculture, 6: 143-150.

Sisman, C., and Delibas, L. 2004. storing sunflower seed and quality losses during storage, Journal of Central European Agriculture. 4: 239-250. 
Spano, C., R., Buselli, M.R., Castiglione, Botteg, S., and Grillia, I., 2006. Rnases and nucleases in embryos and endosperms from naturally aged wheat seeds stored in different conditions. Journal of Plant Physiology. 164: 487-495.

Squadriato, G. L., and Peyor, W. A. 1998. Oxidative chemistry of nitric oxide: the role of superoxide, peroxynitrite, and carbon dioxide. Free Radical Biology and Medicine. 25, 392-403.

Sreenivasulu, N., Grimm, B., Wobus, U., and Weschke, W. 2000. Differential response of antioxidant compounds to salinity stress in salt-tolerant and saltsensitive seedlings of foxtail millet Setariaitalica. PhysiologiaPlantarum, 109: 435-442.

Taung, U. and Mcdonald, M.B. 1995. Changes in esterase activity associated with peanut ArachishypogaeaL. seed deterioration. Seed Science and Technology, 23: 101-111.

Tian, X., Song, S., and Lei, Y. 2008. Cell Death and Reactive Oxigen Species Metabolism during Accelerated Ageing of Soybean Axes. Russian Journal of Plant Physiology55 :33-40.

Tsugane, K., Kobayashi, K., Niwa, Y., Ohba, Y., Wada, K., and Kobayashi, H. 1999. A recessive Arabidopsis mutant that grows photoautotrophically under salt stress shows enhanced active oxygen detoxification. Plant Cell, 11: 11951206.

Verma, S.S., Tomer, R.P.S., and UrmilVerma. 2003. Loss of viability and vigour in Indian mustard seeds stored under Ambient conditions. Seed Research, 31: 98-101.

Wilson, D.O. and Mcdonald, M.B. 1986. The lipid peroxidation model of seed ageing. Seed Science and Technology, 14: 269-300.

Xu, P.L. Guo, Y.K., Bai, J.G., Shang, L., and Wang, X.J. 2008. Effects of longterm chilling on ultrastructure and antioxidant activity in leaves of two cucumber cultivars under low light. PhysiologiaPlantarum, 132: 467-478.

Yildrim, A., Oktay, M., and Bilaloglu, V. 2001. The antioxidant activity of the leaves of Cydonia vulgaris. Turkish Journal of Medical Sciences. 31, 2327.

Yordanov, I., Velikova, V., Tsonev, T. 2000. Plant responses to drought, acclimation, and stress tolerance. Photosynthetica, 38: 171-186.

Zhang, R.P., Wang, Z.Y., Gao, J.F. and Xue, G. 1993. The effects of pre-treatment with PEG on the lipoxygenase LOX activity and protein contents of the soybean Glycinemax hyptocotyl. Soybean Science, 12: 335-339.

\section{How to cite this article:}

Prashant Kumar Mishra, Seema Paroha and Ravi Prakash Mishra. 2016. A Review on Effects of Storage on the Quality and Viability Characteristics of Major Oil Seeds. Int.J.Curr.Res.Aca.Rev. 4(1): 108-121. doi: http://dx.doi.org/10.20546/ijcrar.2016.401.010 